\title{
PENGARUH UKURAN PERUSAHAAN (SIZE) DAN STRUKTUR MODAL TERHADAP NILAI PERUSAHAAN
}

\author{
Marista Oktaviani $^{1}$, Asyidatur Rosmaniar ${ }^{2}$, Samsul Hadi $^{3}$ \\ 1,2,3 Fakultas Ekonomi dan Bisnis Universitas Muhammadiyah Surabaya
}

\begin{abstract}
The purpose of this research is to find out whether the size of the company (SIZE) and the Capital Structure of the Value of the Company with the Distribution of Dividends as a variable intervening. The study period was 2011-2015 with a sample of 400 manufacturing companies listed on the IDX. Data analysis using PLS Warp. SIZE results have a significant negative effect on PBV, capital structure does not affect PBV, dividend distribution has a significant positive effect on PBV, SIZE and capital structure has a positive effect on PBV, dividend distribution can mediate SIZE against PBV, and Dividend Distribution cannot mediate Capital Structure PBV.
\end{abstract}

Keywords : SIZE. Capital Structure, Dividend Distribution of Company Values

Correspondence to :maristaokta48@gmail.com

\begin{abstract}
ABSTRAK
Tujuan dalam penelitian ini untuk mengetahui apakah ukuran perusahaan (SIZE) dan Struktur Modal terhadap Nilai Perusahaan dengan Pembagian Dividen sebagai variable intervening. Periode penelitian ini 2011-2015 dengan sampel 400 perusahaan manufaktur yang terdaftar di BEI. Analisis data menggunakan Warp PLS. Hasil penelitian SIZE berpengaruh negatif siginifikan terhadap PBV, Struktur modal tidak berpengaruh terhadap PBV, Pembagian dividen berpengaruh positif signifikan terhadap PBV, SIZE dan struktur modal berpengaruh positif ke PBV, Pembagian dividen dapat memediasi SIZE terhadap PBV, dan Pembagian Dividen tidak dapat memediasi Struktur Modal terhadap PBV.
\end{abstract}

Kata kunci

:SIZE. Struktur Modal, Pembagian Dividen an Nilai Perusahaan

Korespondensi : maristaokta48@gmail.com

\section{PENDAHULUAN / INTRODUCTION}

Perusahaan go public memiliki tujuan untukpeningkatan para kemakmuran pemilik atau para pemegang saham melalui kenaikan nilai perusahaan (Salvatore, 2005). Nilai perusahaan yang tinggi sangat penting bagi perusahaan dapat diikuti oleh kemakmuran pemegang saham (Brigham \& Gapenski, 2006). Kemakmuran para pemegang saham mencerminkan bahwa perusahaan tersebut memiliki nilai perusahaan yang baik, adanya kekayaan yang dimiliki para pemegang saham dan perusahaan dapat dipresentasikan oleh harga pasar saham yang merupakan cerminan dari keputusan investasi, pendanaan (financing), dan manajemen asset. 
Ukuran dari sebuah perusahaan juga ikut menentukan nilai perusahaan. Ukuran perusahaan (SIZE) merupakan suatu indikator dari kekuatan financial suatu perusahaan (Hermuningsih, 2013). Dewi and Wirajaya (2013) dan Pantow, S. Murni, and Trang (2015), bahwa besarnya skala perusahaan semakin mudah perusahaan memperoleh sumber pendanaan baik internal maupun eksternal, sumber dana yang diperoleh mendukung kegiatan operasional sehingga meningkatkan harga saham perusahaan tersebut. Peningkatan harga saham perusahaan maka peningkatan nilai perusahaan dapat ditentukan oleh harga saham yang tercantum di Bursa Efek. Harga saham tinggi menunjukan bahwa perusahaan tersebut mampu meningkatkan kinerjanya secara baik dan nilai perusahaan naik (Wulandari, 2013).

Teori struktur modal merupakan teori mengenai pendanaan perusahaan berupa utang dan ekuitas untuk memaksimumkan nilai perusahaan (Hamidy, Wiksuana, \& Artini, 2015). Teori trade off menjelaskan bahwa semakin tinggi struktur modal maka nilai perusahaan akan meningkat selama utang tidak pada batas maksimal. Nilai perusahaan merupakan presepsi investor terhadap keseluruhan atas setiap ekuitas yang dimiliki perusahaan yang dikaitkan dengan harga saham. Harga saham yang digunakan umumnya mengacu pada harga penutupan (closing price), dan merupakan harga yang terjadi pada saat saham diperdagangkan di pasar Sari and Priyadi (2017). Nilai perusahaan yang tinggi mampu meningkatkan kepercayaan investor terhadap kinerja dan prospek perusahaan dimasa depan.

Penelitian yang berjudul SIZE, dan Struktur Modal berpengaruh terhadap Nilai Perusahaan dengan Pembagian dividen sebagai variable intervening, alasan peneliti meneliti hal ini karena menemukan gap pada penelitian terdahulu ukuran perusahaan yang besar, dengan laba tinggi dapat meningkatkan nilai perusahaan (Gill, Biger, Mand, \& Mathur, 2013; Iturriaga \& Crisostomo, 2010; Nuraina, 2012; Nurhayati, 2013), namun penelitian Garay and González (2008) dan Dewi and Wirajaya (2013) menyatakan perusahaan dengan skala besar akan lebih mudah memperoleh hutang, terkait dengan tingkat kepercayaan kreditur kepada perusahaan besar. Peneliti menggunakan perusahaan manufaktur di Bursa Efek Indonesia dikarenakan perusahaan manufaktur pada lima tahun terakhir ini, tidak terlalu bagus kenaikan keuntungan pada harga saham. Tujuan dalam penelitian ini untuk mengetahui apakah SIZE, dan Struktur Modal terhadap Nilai Perusahaan dengan Pembagian Dividen sebagai variable intervening.

\section{KAJIAN TEORI}

\section{Teori Sinyal}

Signaling theory adalah tindakan yang dilakukan oleh pemilik lama saham yang memberikan informasi kepada investor tentang kinerja perusahaan serta nilai perusahaan dimasa datang, sinyal positif para investor menanamkan sahamnya pada perusahaan (Widarjo, 2011). Perlu adanya dorongan pada pihak perusahaan yang memberikan sinyal pada pihak investor yang bertujuan memberikan informasi mengenai besarnya nilai perusahaan. Menurut Jogiyanto (2010) informasi yang dipublikasikan sebagai suatu pengumuman akan memberikan signal bagi investor dalam pengambilan keputusan investasi.

\section{Teori Trade Off}

Trade off theory ini dikenal dengan nama balanced theory. Husnan (2006) mengatakan balanced theory ialah adanya keseimbangan antara keuntungan penggunaan dana dari utang dengan tingkat bunga yang tinggi dan biaya kebangkrutan. Teori trade off merupakan penyeimbang manfaat dan pengorbanan yang timbul sebagai akibat penggunaan utang. Teori trade off, berperan 
mempertahankan adanya struktur modal yang ditargetkan dengan tujuan memaksimumkan nilai pasar (Sartono, 2002).

\section{Nilai Perusahaan}

Nilai perusahaan merupakan suatu nilai yang dimiliki oleh perusahaan saat perusahaan akan dijual. Aziza (2015)menyatakan nilai perusahaan ialah nilai pasar atas saham yang dimiliki perusahaan yang sudah go public jika belum go public maka nilai perusahaan adalah nilai yang terjadi apabila perusahaan tersebut dijual. Pengukuran nilai perusahaan dengan Price to book value (PBV), pengukuran ini dinilai sangat penting bagi investor untuk menetapkan strategi investasi di pasar modal.

\section{PembagianDividen}

Dividen adalah pembagian laba perusahaan kepada para pemegang saham. Dividen yang dibagikan merupakan sinyal bagi pihak investor dalam menilai kinerja perusahaan serta menjadi sumber pendapatan investor(Wang, Yang, \& Liu, 2017).

\section{Ukuran Perusahaan (SIZE)}

Nuraina (2012) Ukuran perusahaan menggambarkan besar kecilnya suatu perusahaan yang ditunjukkan pada total asset, jumlah penjualan, rata-rata total penjualan, dan rata-rata total asset. Jadi, ukuran perusahaan merupakan hasil pencapaian oleh perusahaan dalam meningkatkan kepercayaan masyarakat terhadap perusahaan setelah melalui beberapa proses dan besarnya aset yang dimiliki oleh suatu perusahaan.

\section{Struktur Modal}

Keown, Petty, and Scott (2005)menjelaskan bahwa struktur modal pendanaan jangka panjang yang digunakan perusahaan dalam memaksimalkan kekayaan pemegang saham, sehinga pihak manajer keuangan dapat menilai struktur modal dan memahami risiko, serta hasil dari pengembalian nilai.

\section{HIPOTESIS}

\section{SIZE berpengaruh terhadap Nilai Perusahaan.}

Ukuran perusahaan yang besar memiliki kemungkinan nilai perusahaan akan turun. Hasil penelitian Nuraina (2012) dan Prasetia, Tommy, and Saerang (2014), menjelaskan bahwa ukuran perusahaan yang besar dapat mudah untuk masuk ke pasar modal. Perusahaan memiliki kemampuan mendapatkan dana karena akses ke pasar modal lebih bersifat fleksibilitas, jika perusahaan memiliki kemudahan aksebilitas ke pasar modal cukup berarti fleksibilitas dan kemampuannya untuk memunculkan dana lebih besar (Nurhayati, 2013). Besar kecilnya nilai perusahaan akan berpengaruh terhadap nilai perusahaan dengan didasarkan pada kenyataan bahwa semakin besar suatu perusahaan mempunyai tingkat penambahan aset yang tinggi sehingga dapat memperoleh laba yang akan berpengaruh terhadap nilai perusahaan. Dewi and Wirajaya (2013), Anjarwati, Chabachib, and Demi (2016) dan Juan (2012) menunujukkan bahwa size berpengaruh terhadap nilai perusahaan.

H1 : SIZE berpengaruh positif terhadap nilai perusahaan

\section{Struktur Modal berpengaruh terhadap Nilai} Perusahaan.

Trade-off Theory manfaat dari peningkatan utang masih lebih besar dari pengorbanan yang dikeluarkan sehingga secara langsung manfaat penggunaan utang tersebut meningkatkan nilai perusahaan. Struktur modal merupakan kunci perbaikan produktivitas dan kinerja perusahaan dari perbandingan jumlah utang dan ekuitas. Peningkatan nilai perusahaan karena peningkatan jumlah utang (utang yang masih di bawah titik optimalnya) disebabkan oleh manajemen perusahaan yang menggunakan utang tersebut untuk ekspansi usaha dari perusahaan(Velnampy \& Niresh, 2012). Sesuai dengan Trade-off Theory dimana penggunaan utang dapat mengurangi pajak 
dan mengurangi biaya agensi yang dapat menyebabkan nilai perusahaan baik dan lebih efisien. Semakin tinggi DER berarti semakin besar jumlah modal yang digunakan sebagai modal investasi sehingga PBV meningkat.

$\mathrm{H} 2$ : Struktur Modal berpengaruh positif terhadap Nilai Perusahaan

\section{Pembagian dividen berpengaruh terhadap} Nilai Perusahaan

Kebijakan dividen adalah $\begin{array}{r}\text { sebuah } \\ \text { dengan }\end{array}$
keputusan angan,
mempertimbangkan apakah pembayaran
dividen akan meningkatkan kemakmuran
pemegang saham (Mursalim, 2011).
Pembagian dividen dilakukan dengan
pembayaran dividend payout ratio kepada
para pemegang saham serta meningkatkan
harga saham sehingga nilai perusahaan naik.
H3 : Pembagian dividen berpengaruh
positif terhadap nilai perusahaan

\section{SIZE berpengaruh terhadap Pembagian Dividen}

Ukuran perusahaan yang besar mencerminkan semakin tinggi omset yang dimiliki, hal ini dapat menyebabkan keuntungan juga meningkat, jika laba meningkat maka dividen yang akan dibagikan juga meningkat (Lopolusi, 2013). Hasil penelitian Christianty (2008) dan Crutchley and Hansen (1989) menyatakan ukuran perusahaan yang besar cenderung pihak perusahaan selalu membagikan dividen, dan dividen yang dibagikan terus meningkat. Namun penelitian Nurhayati (2013) dan Pribadi and Sampurno (2012)menyatakan ukuran perusahaan yang besar dapat menurunkan pembagian dividen dikarenakan semakin besarnya perusahaan menyebabkan banyak persaingan sehingga semakin berat beban yang ditanggung maka mengurangi pembagian dividen.

H4 :SIZE berpengaruh positif terhadap Pembagian Dividen

\section{Struktur Modal berpengaruh terhadap} Pembagian Dividen
Hasil penelitian Gupta and Banga (2010) dan Lopolusi (2013) bahwa semakin besar hutang perusahaan atau semakin meningkatnya hutang yang digunakan dalam struktur modal maka semakin pula kewajiban. Peningkatan hutang mempengaruhi pembagian dividen yang rendah dikarenakan pihak perusahaan lebih mengutamakan membayar hutang daripada membagikan dividen.

H5 : Struktur modal berpengaruh negatif terhadap pembagian dividen

Pembagian Dividen memediasi SIZE terhadap Nilai Perusahaan

Ukuran perusahaan dapat meningkatkan nilai perusahaan, dikarenakan ukuran perusahaan yang besar mencerminkan perusahaan memiliki laba yang besar (Nuraina, 2012; Tommy \& Saerang, 2014). Jika semakin besar laba yang dihasilkan perusahaan dapat menyebabkan semakin besar pula pembagian dividen, karena investor cenderung meminta dividen dibagikan pada saat laba perusahaan tinggi, sehingga pembagian dividen dapat memediasi ukuran perusahaan terhadap nilai perusahaan.

H6 : Pembagian dividen dapat memediasi SIZE terhadap Nilai Perusahaan.

\section{Pembagian Dividen memediasi Struktur} Modal terhadap Nilai Perusahaan

Struktur modal yang berupa hutang perusahaan, pada saat struktur modal pada titik optimal maka setiap adanya penambahan hutang dapat menurunkan nilai perusahaan, maka sebaliknya jika hutang dibawah titik optimal maka dapat menaikkan nilai perusahaa hal ini sejalan dengan teori trade off adanya hubungan positif dengan struktur modal. Hasil penelitian Apriada and Suardikha (2016) dan Dewi and Wirajaya (2013) mejelaskan bahwa struktur modal berpengaruh positif terhadap nilai perusahaan. Nilai struktur modal semakin tinggi maka tidak dapat meningkatkan pembagian dividen 
perusahaan lebih memilih membayar hutang Gupta and Banga (2010).
H7 : Pembagian Dividen tidak dapat memediasi pengaruh SIZE terhadap Nilai Perusahaan

\section{KERANGKA PEMIKIRAN}

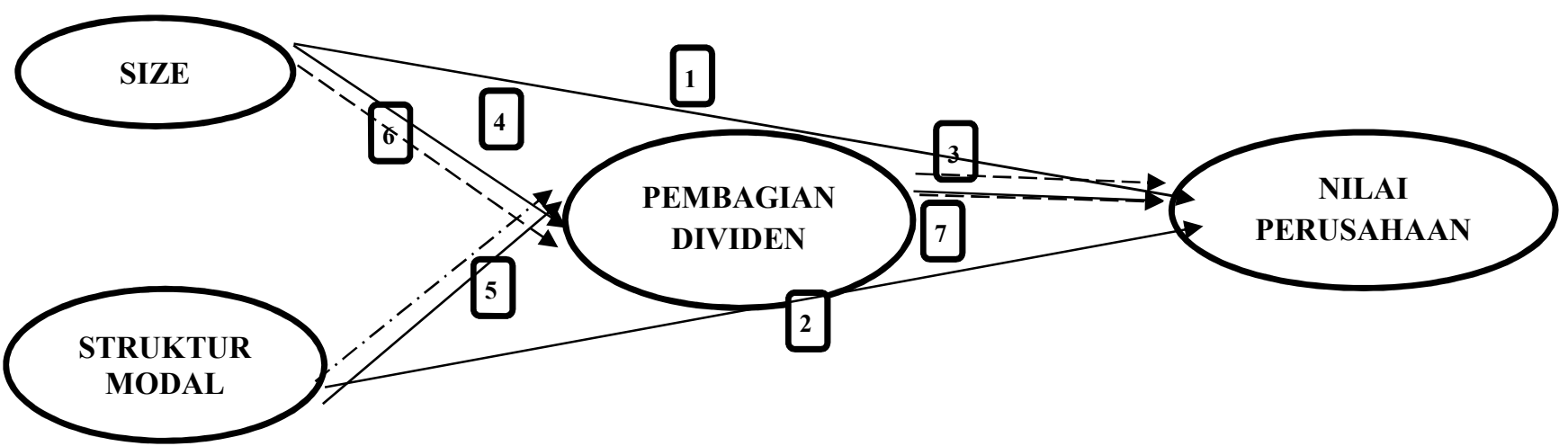

Keterangan :

H1 : SIZE berpengaruh terhadap Nilai Perusahaan

H2 : Struktur Modal berpengaruh terhadap Nilai Perusahaan

H3 : Pembagian Dividen berpengaruh terhadap Nilai Perusahaan

H4 : SIZE berpengaruh terhadap Pembagian Dividen

H5 : Struktur Modal berpengaruh terhadap Pembagian Dividen

H6 : Pembagian Dividen memediasi SIZE terhadap Nilai Perusahaan

H7 : Pembagian Dividen memediasi Struktur Modal terhadap Nilai Perusahaan

\section{METODE PENELITIAN / METHODS}

Pendekatan penelitian dan Sumber Data

$$
\text { Penelitian ini menggunakan }
$$

pendekkatan kuantitatif. Jenis penelitian asosiatif menggunakan data-data sekunder pada perusahaan manufaktur yang terdaftar di Bursa Efek Indonesia. Jenis data sekunder, yaitu data berupa laporan keuangan tahunan perusahaan manufaktur yang terdaftar di BEI tahun 2011-2015. Data yang diperoleh berupa laporan keuangan perusahaan manufaktur yang listing di BEI, bersumber dari pusat Referensi Pasar Modal dan Indonesia Capital Market Directory, situs resmi www.idx.co.id serta informasi lain yang bersumber literatur yang terkait penelitian ini.
Populasi perusahaan manufaktur yang terdaftar di Bursa Efek Indonesia (BEI). Periode penelitian tahun 2011-2015. Jumlah sampel pada penelitian ini sebanyak 400 perusahaan manufaktur menggunakan metode purposive sampling. Kriteria sampel yang digunakan (a) Perusahaan manufaktur yang terdaftar di BEI 2011-2015, (b) Perusahaan yang menerbitkan laporan keuangan telah diaudit pada periode yang berakhir 31 Desember tahun 2011-2015, (c) Perusahaan manufaktur yang menerbitkan laporan keuangan dengan mata uang rupiah tahun 2011-2015.

Definisi Operasional

Ukuran Perusahaan (SIZE)

$$
S I Z E=\log \text { total asset }
$$

Populasi dan Sample

Struktur Modal 


$$
\frac{\text { Total Kewajiban }}{\text { Ekuitas }} \times 100 \%
$$

Variabel Terikat (Dependent Variabel / Endogen Variabel)

Nilai Perusahaan :

harga pasar perlembar saham biasa nilai buku perlembar saham biasa

Variabel Intervening

Pembagian Dividen

Divided payout ratio (DPR) menurutHusnan (2006) :

$$
D P R=\frac{\text { Dividen perlembar saham }}{\text { Laba perlembar saham }}
$$

\section{Teknik Analisis Data}

Pengujian hipotesis dilakukan dengan metode Partial Least Square (PLS). PLS adalah metode penyelesaian structual equation modelling (SEM). Pengujian data dalam peneliti menggunakan analisis SEM

\section{HASIL PENELITIAN DAN PEMBAHASAN / RESULTS AND DISCUSSION HASIL PENELITIAN}

Tabel 1. Model Fit

\begin{tabular}{ll}
\hline Model fit indices & $\mathrm{P}$ values \\
\hline $\mathrm{APC}=0.133$ & $\mathrm{P}=<0.001$ \\
$\mathrm{ARS}=0.057$ & $\mathrm{P}=0.184$ \\
$\mathrm{AVIF}=1.057$ & Good if $<5$ \\
\hline
\end{tabular}

\section{Path coefficients dan P-values}

dengan aplikasi WarpPLS 3.0. Analisis data menggunakan model outer dan inner model.

Pengujian hipotesis menggunakan nilai probabilitas dan nilai t-statistik, dengan nilai p-value dengan alpha 5\%. Nilai t-tabel alpha $5 \%$ adalah 1,96. Kriteria adalah

a. Jika nilai t-statistik lebih kecil dari ttabel, maka $\mathrm{H}_{0}$ diterima dan $\mathrm{H}_{\mathrm{a}}$ ditolak

b. Jika nilai $\mathrm{t}$-statistik lebih besar atau $=\mathrm{t}$ tabel, $\mathrm{H}_{0}$ ditolak dan $\mathrm{H}_{\mathrm{a}}$ diterima

Persamaan pada penelitian ini :

$$
\begin{aligned}
Y=a+\beta_{1} X_{1} & +\beta_{2} X_{2}++\beta_{3} Z_{1}+\beta_{4} X_{1} Z_{1} \\
& +\beta_{5} X_{2} Z_{1}++\beta_{6} X_{1} Z_{2} \\
& +\beta_{7} X_{2} Z_{2}+e
\end{aligned}
$$

Keterangan :

$\mathrm{Y}=$ Nilai perusahaan sektor barang konsumsi

a $\quad=$ Konstanta

$X_{1}=S I Z E$

$X_{2} \quad=$ Struktur Modal

$Z_{2} \quad=$ Pembagian Dividen (Mediasi)

Tabel 1 menunjukkan indikator model fit dengan APC 0.133 P-Value $<0.001$, ARS 0,057 dan $\mathrm{P}$ value sebesar 0.184. Nilai AVIF sebesar 1.057 memenuhi syarat kurang dari 5, dalam data penelitian diuji dengan model fit dan data penelitian dinyatakan fit sehingga data penelitian ini tidak terjadi multikolirearitas.

Tabel 2. Path Koefisien

\begin{tabular}{lllll}
\hline & Struktur Modal & SIZE & Dividen & PBV \\
\hline Struktur modal & & & & \\
SIZE & & & & \\
Dividen & 0.074 & 0.291 & & \\
PBV & -0.051 & -0.108 & 0.141 & \\
\hline
\end{tabular}

\begin{tabular}{lllll}
\multicolumn{5}{c}{ P Values } \\
\hline & Struktur Modal & SIZE & Dividen & PBV \\
\hline Struktur modal & & & & \\
SIZE & & & \\
Dividen & 0.049 & $<0.001$ & \\
PBV & 0.294 & 0.005 & $<0.001$ & \\
\hline
\end{tabular}


Nilai dari SIZE dengan p-value 0,005 dan koefisien $-0,108$, dan pembagian dividen p-value $<0.001$ dengan koefisien 0.14 yang artinya berpengaruh signifikan, struktur modal p-values 0.29 dengan koefisien -0.05 artinya tidak berpengaruh terhadap PBV. SIZE ke DEV P-value $<0.001$ koefisien 0.29, struktur modal p-value 0.005 koefisien 0.07 yang artinya berpengaruh terhadap pembagian dividen.

\section{Uji Mediasi}

Baron and Kenny (1986)menyatakan adanya pengaruh antara variabel dependen berhubungan tidak secara langsung terjadi namun melalui proses tranformasi yang diwakili oleh variabel mediasi.

Tabel 3. Uji Mediasi SIZE-DEV-PBV

\begin{tabular}{lll}
\hline Pengaruh Tidak Langsung & & \\
SIZE - DEV - PBV & $0,29 \times(-0,11)=$ & 0,0319 \\
Pengaruh Langsung SIZE - PBV & $0,11+0,001=$ & 0,1111 \\
$\quad$ Total & & 0,1430 \\
VAF & $0,0319 / 0,143=$ & 0,2250 \\
\hline
\end{tabular}

Uji Mediasi SIZE-DEV-PBV

\begin{tabular}{lll}
\hline Pengaruh Tidak Langsung & \\
STR_MO - DEV - PBV & $0,07 \times(-0,05)=$ & 0,0035 \\
Pengaruh Langsung STR_MO - PBV & $0,05+0,29=$ & 0,344 \\
\multicolumn{1}{c}{ Total } & & 0,3435 \\
VAF & $0,0035 / 0,3435=$ & 0,010 \\
\hline
\end{tabular}

Hasil penelitian bahwa pembagian dividen dapat memediasi size terhadap nilai perusahaan dengan total VAF sebar 0,2250 atau $22,5 \%$ yang dapat diartikan memiliki pengaruh mediasi sedang karena melebihi dari $20 \%$ Apabila VAF berkisaran antara 20\%-
80\% dikatakan pemediasi parsial (Sholihin \& Ratmono, 2013). Pembagian dividen tidak dapat memediasi struktur modal terhadap nilai perusahaan dengan nilai VAF 0,01 atau $1 \%$. Inner Model

\begin{tabular}{ccccc}
\multicolumn{5}{c}{ Tabel 4. Inner Model } \\
\hline & PBV & SIZE & STR_MO & DEV \\
\hline R-Square & 0,024 & & & 0,09 \\
Combach Alpha & 1.000 & 1.000 & 1.000 & 1.000 \\
Full collin VIF & 1.020 & 1.100 & 1.008 & 1.116 \\
Q-square & 0.030 & & & 0.092 \\
\hline
\end{tabular}

Hasil penelitian ini mengenai nilai perusahaan, $R$-square sebesar 0,024 atau $2 \%$, sedangkan hubungan secara langsung SIZE, dan STR_MO terhadap pembagian dividen 0,09 atau $9 \%$, yang dapat diartikan bahwa adanya pengaruh dalam hasil penelitian ini. Nilai Q-square menunjukkan nilai validitas prediktif $>0$ maka data penelitian sudah kontruksi dengan baik mempunyai relevasi prediktif PBV 0,030 dan DAR 0,092. Penilaian dengan full collinearity VIF pada variabel penelitian ini dapat dinyatakan bebas dari kolinearitas karena kurang dari 3,3.

\section{PEMBAHASAN}

a. Pengaruh SIZE terhadap Nilai Perusahaan

Hasil pengujian SIZE berpengaruh nilai perusahaan bahwa $\mathrm{H} 1$ diterima dan $\mathrm{H} 0$ ditolak, yang diartikan bahwa nilai $p$-value < 0.001 dan koefisien -0,11 maksudnya SIZE berpengaruh negatif signifikan. Nilai 
perusahaan tidak hanya bisa diukur dengan besarnya ukuran perusahaan. Pada saat ukuran perusahaan besar dapat menyebabkan kemungkinan nilai perusahaan turun. Hasil penelitian terdahulu menurut Nuraina (2012) dan Prasetia et al. (2014), menjelaskan ukuran perusahaan yang besar dapat lebih mudah masuk kepasar modal Perusahaan memiliki kemampuan mendapatkan dana dari pihak ekternal karena akses kepasar modal lebih fleksibilitas, pada saat perusahaan memiliki kemudahan aksebilitas ke pasar modal berarti fleksibilitas dan kemampuannya untuk memunculkan dana lebih besar (Nurhayati, 2013).

Pada sisi lain hasil penelitian Garay and González (2008) dan Dewi and Wirajaya (2013) menyatakan bahwa ukuran perusahaan yang besar akan lebih mudah memperoleh hutang dari pihak eksternal. Hutang yang diperoleh perusahaan digunakan untuk berinvestasi, namun presepsi investor tidak mau mengambil risiko pada saat perusahaan memiliki hutang yang berlebih oleh sebab itu nilai perusahaan menurun. Namun hasil penelitian Mahardhika and Roosmawarni (2016) bahwa SIZE tidak berpengaruh terhadap PBV.

\section{b. Pengaruh Struktur Modal terhadap Nilai Perushaan}

Hasil penelitian Struktur Modal tidak berpengaruh terhadap nilai perusahaan bahwa $\mathrm{H} 2$ ditolak dan $\mathrm{H} 0$ diterima, artinya nilai pvalue 0,29 dan koefisien $-0,05$ nilai $p$-value melebihi 0,05 sehingga tidak dapat berpengaruh secara langsung. Struktur modal yang tinggi tidak dapat meningkatkan nilai perusahaan. Perushaan yang memiliki hutang yang besar, dan menggunakan hutang tersebut sebagai sumber pendanaan daripada ekuitas hal ini dapat menurunkan nilai perusahaan. Penelitian ini didukung oleh hasil penelitian Apriada and Suardikha (2016) dan Safrida (2008) menjelaskan bahwa struktur modal tidak berpengaruh terhadap nilai perusahaan.

\section{c. Pengaruh Pembagian Dividen terhadap Nilai Perusahaan}

Hasil penelitian pembagian dividen berpengaruh terhadap nilai perusahaan $\mathrm{H} 3$ diterima dan $\mathrm{H} 0$ ditolak yang artinya nilai $\mathrm{p}$ value $<0,001$ dan koefisien 0,14. Pembagian dividen yang dilakukan perusahaan melalui dividend payout ratio mengalami peningkatan maka nilai perusahaan juga akan meningkat. Pihak manajemen perusahaan setiap tahunya membagikan dividen kepada pemegang saham, sehingga perusahaan memberikan signal positif kepada investor lainnya dengan tujuan menunjukkan bahwa perusahaan memiliki nilai yang tinggi. Hatta (2002)menyatakan bahwa kebijakan dividen sering dianggap sebagai signal bagi investor untuk menilai perusahaan. Penelitian ini sejalan dengan Ansori and H.N (2010)dan Mursalim (2011) Pembagian dividen merupakan keputusan pembayaran dividen tahunan perusahan yang mempertimbangkan maksimalisasi harga saham saat ini dan akan datang.

\section{d. SIZE berpengaruh terhadap Pembagian Dividen}

Hasil penelitian H4 SIZE berpengaruh terhadap pembagian dividen dinyatakan $\mathrm{H} 4$ Diterima $\mathrm{H} 0$ ditolak, nilai $\mathrm{p}$ value $<0.001$ dan koefisien 0,29. Hasil pengujian jika ukuran perusahaan semakin besar maka semakin tinggi pula pembagian dividen. Perusahaan dengan ukuran besar cenderung membagikan dividen yang tinggi dengan tujuan menjaga reputasi dikalangan investor. Besarnya perusahaan mencerminkan perusahaan memiliki laba yang besar sehingga dapat membagikan dividen yang besar pula. Penelitian ini didukung oleh hasil penelitian Crutchley and Hansen (1989), Christianty (2008) dan Kuniawan, Arifati, and Andini (2012) yang menyatakan pembagian dividen yang tinggi didukung dengan besarnya ukuran perusahaan. 


\section{e. Struktur Modal terhadap Pembagian Dividen}

Hasil penelitian H5 Struktur Modal berpengaruh terhadap pembagian dividen dinyatakan $\mathrm{H} 5$ ditolak dan $\mathrm{H} 0$ diterima dengan pvalue 0,05 dan koefisien 0,07 yang diartikan bahwa struktur modal berpengaruh positif signifikan terhadap pembagian dividen. Hasil penelitian ini tidak sejalan dengan Ismiyanti and Hanafi (2003) dan Gupta and Banga (2010) yang menyatakan semakin besar hutang yang dimiliki perusahaan maka dapat menurunkan pembagian dividen, namun hasil penelitian ini menyatakan struktur modal yang tinggi dapat meningkatkan pembagian dividen dikarenakan perusahaan yang memiliki proposi hutang besar dan hutang tersebut digunakan untuk mengembangkan perusahaan, dan perusahaan memiliki kewajiban untuk membagikan dividen.

\section{f. Pembagian Dividen memediasi SIZE terhadap Nilai Perusahaan}

Hasil pengujian H6 menyatakan pembagian dividen dapat memediasi SIZE terhadap Nilai Perusahaan, dengan hasil hipotesis pengujian mediasi VAF $22,5 \%$ yang artinya H6 diterima dan H0 ditolak. Tommy and Saerang (2014) dan Gill et al. (2013) menyatakan Ukuran perusahaan yang besar dapat meningkatkan nilai perusahaan. Ukuran perusahaan yang besar cenderung perusahaan akan membagikan dividen yang tinggi, dikarenakan reputasi perusahaan di mata investor dianggap baik. Perusahaan yang membagikan dividen tinggi dapat dilihat jika ukuran perusahaan yang besar maka laba yang dimiliki perusahaan juga besar sehingga perusahaan dapat memberikan signal positif terhadap investor menyakinnkan investor yang akan menanam sahamnya menunjukkan bahwa perusahaan sanggup membayar dividen setiap tahunnya hal ini diikuti oleh kenaikan nilai perusahaan.

\section{g. Pembagian Dividen memediasi Struktur Modal terhadap Nilai Perusahaan}

Hasil penelitian $\mathrm{H} 7$ bahwa pembagian dividen tidak dapat memediasi struktur modal terhadap nilai perusahaan maka $\mathrm{H} 7$ diterima dan H0 ditolak. Teori trade off menjelaskan struktur modal dibawah titik optimal maka setiap hutang perusahaan bertambah akan meningkatkan nilai perusahaan, sebaliknya jika posisi struktur modal berada diatas titik optimal maka penambahana hutang akan menurunkan nilai perusahaan. Hasil penelitian Apriada and Suardikha (2016) menyatakan struktur modal tidak dapat meningkatkan nilai perusahaan dikarenakan sebagian besar penggunaan hutang sebagai sumber pendanaan perusahaan daripada ekuitas sehingga berpengaruh pada menurunnya nilai perusahaan.Jensen (1986)dalam Christianty (2008) menyatakan penggunaan hutang yang teralu tinggi menyebabkan penurunan dividen dimana sebagaian besar keuntungan akan digunakan untuk melunasi hutang. Jadi pembagian dividen tidak dapat memdiasi terhadap struktu modal dan nilai perusahaan, logikanya penggunaan hutang yang berlebihan maka nilai perusahaan turun dan tidak ada dividen yang dibagikan kepada pemegang saham.

\section{KESIMPULAN, SARAN DAN KETERBATASAN PENELITI/ CONCLUSSION \\ KESIMPULAN}

Ukuran perusahaan (SIZE) dan Struktur Modal berpengaruh terhadap Nilai perusahaan, dengan menggunakan variable intervening Pembagian Dividen. Hasil penelitian ini dapat disimpulkan SIZE berpengaruh negatif signifikan terhadap PBV, Pembagian Dividen dapat berpengaruh positif terhadap PBV, Struktur Modal tidak berpengaruh terhadap Nilai Perusahaan. Pembagian Dividen dapat memedisi antara 
SIZE terhadap PBV, namun Pembagian Dividen tidak dapat memediasi Struktur Modal terhadap Nilai Perusahaan.

\section{SARAN}

Beberapa saran yang dapat diberikan: (1) Bagi peneliti selanjutnya, diharapkan menghilangkan sampel perusahaan yang mengalami kerugian/kebangkrutan, mengganti obyek perusahaan yang diteliti dan memperpanjang periode pengamatan dari yang sebelumnya dengan menggunakan tahun terbaru; (2) Penelitian ini menggunakan sampel perusahaan manufaktur terdaftar di BEI dengan periode 5 tahun. Akan lebih baik menambahkan atau mengurangi variabel lain seperti dividen payment, cash flow, likuiditas dan sebagainya sehingga nilai R-Square dapat ditingkatkan nilainya dan permodelan menjadi lebih baik; (3) Bagi manajemen dapat mengetahui kenaikan nilai perusahaan, misalnya dividen yang dibagikan kepada pemegang saham dan tingkat hutang perusahaan, sedangkan bagi pihak investor yang akan menanamkan saham, maka dapat melihat kenaikan nilai perusahaan dengan melihat seberapa besar hutang yang ada diperusahaan dan tingkat pembagian dividen.

\section{DAFTAR PUSTAKA / BIBLIOGRAPHY}

Anjarwati, K., Chabachib, M., \& Demi, I. R. (2016). Pengaruh Profitabilitas, SIZE, dan Likuiditas Terhadap Nilai Perusahaan Manufaktur di Indonesia dengan Struktur Modal sebagai Variabel Intervening. Diponegoro Journal of Finance, 1(1).

Ansori, M., \& H.N, D. (2010). Pengaruh Keputusan Investasi Keputusan Pendanaan Dan Kebijakan Dividen Terhadap Nilai Perusahaan Pada
Perusahaan Yang Tergabung Dalam Jakarta Islamic Index Studi Pada Bursa Efek Indonesia ( BEI ). Analisis Manajemen, 4(2), 153-175.

Apriada, K., \& Suardikha, M. S. (2016). Pengaruh Struktur Kepemilikan Saham, Struktur Modal Dan Profitabilitas Pada Nilai Perusahaan. E-Jurnal Ekonomi dan Bisnis Universitas Udayana, 5(2), 201-218.

Aziza, S. A. (2015). Pengaruh Free Cash Flow, Dividend, Leverage dan Good Corporate Governance Terhadap Nilai Perusahaan Pada Perusahaan Manufaktur Yang Terdaftar Di Bursa Efek Indonesia. Journal Riset Mahasiswa Akuntansi (JRMA), 2(2), 1-11.

Baron, R. M., \& Kenny, D. A. (1986). The Moderator-Mediator Variable Distinction in Social Psychological Research: Conceptual, Strategic, and Statistical Considerations. Journal of Personality and Social Psychology, 51(6), 1173-1182.

Brigham, E. F., \& Gapenski, L. C. (2006). Intermediate Financial Management. SeaHarbor: The Dryden Press.

Christianty, D. S. (2008). Pengaruh kepemilikan managerial, kepemilikan institusional, kebijakan hutang, profitabilitas dan ukuran perusahaan terhadap kebijakan dividen. Jurnal Bisnis dan Akuntansi, 10(1), 47-58.

Crutchley, C. E., \& Hansen, R. S. (1989). A test of the agency theory of managerial ownership, corporate leverage, and corporate dividends. Financial Management, 36-46.

Dewi, A. S. M., \& Wirajaya, A. (2013). Pengaruh Struktur Modal, Profitabilitas Dan Ukuran Perusahaan Pada Nilai Perusahaan. EJurnal Akuntansi Universitas Udayana, 4(2), 358-372.

Firmansyah, M. A., \& Mahardhika, B. W. (2018). Pengantar Manajemen. Deepublish.

Garay, U., \& González, M. (2008). Corporate Governance and Firm Value: The Case of Venezuela. Journal compilation, 16(3), 194-209. 